\title{
CO-PARASITISM AND MORPHOMETRICS OF THREE CLINOSTOMATIDS (DIGENEA: CLINOSTOMATIDAE) IN Sarotherodon melanotheron FROM A TROPICAL FRESHWATER LAKE
}

\author{
ECHI, Paul Chinedu, EYO, Joseph Effiong and OKAFOR, Fabian Chukwuemenam \\ Department of Zoology University of Nigeria, Nsukka, Enugu State, Nigeria
}

Corresponding Author: Echi, P. C. Parasitology and Public Health Research Unit, Department of Zoology university of Nigeria, Nsukka, Enugu State, Nigeria. Email: paul echi@yahoo.com Phone: +2348038804737

\begin{abstract}
In ever competitive environment of nature, evolution of most attributes of an organism - anatomy, physiology, and behaviour are determined by the environment through selection. The same is the microhabitats of Sarotherodon melanotheron where three Clinostomatids; Clinostomum tilapiae, Clinostomum complanatum, and Euclinostomum heterostomum, were recovered from Opi Lake (GPS N06.75275*, E007.49104*), were studied from (November 2007-October 2008) using multiple fishing gear techniques; cast nets, hook and line, and seine nets (150 mm - $200 \mathrm{~mm})$, showed significant difference $(p<0.05)$ in all other anatomical parts but the distance between oral and ventral suckers. The prevalence was low; (20.8\%) was recorded in C. complanatum, (6.4\%) in E. heterostomum and (21.1\%) in C. tilapiae. But mean intensity was high which was suggestive of heavy parasite burden; C. complanatum (2.7), C. tilapiae (5.8) and E. heterostomum (5.1). In the rank-abundance curve for parasite communities $C$. tilapiae was more abundant than the other two species. Differential parasitic implications was due to selection for relatively better adaptiveness to host's microhabitats, more population size, better host location, and larger body size. Consequently, this resulted in a trade-off between larger morphometric parts and population size among the parasites.
\end{abstract}

Key words: Clinostomum sp, co-parasitism, Morphometrics, E. heterostomum, Opi Lake, Selection

\section{INTRODUCTION}

The present study investigated co-parasitism and morphometrics of Clinostomatids in relation to higher susceptibilities to infection, better adaptiveness and selection in $S$. melanotheron. This has become important as most studies have been based on taxonomy and basic parasite biology. For instance, species of Clinostomum have been described from freshwater fish in Nigeria and many parts of the world. Ukoli (1966) described Clinostomum tilapiae in the intestine of Oreochromis niloticus and Sarotherodon galilaeus in the river Niger. Other species of Clinostomum, e.g. Clinostomum complanatum has been recorded in the fish of river Niger (Ukoli, 1969), Clinostomum sp. were found to be common in Tilapia sp. While those of Euclinostomum sp. were recovered mainly from the osteoglossid Heterotis niloticus. However, in the species of Tilapia, the metacercariae occurred in the sub mucosa of the mouth cavity, gill chamber, below the operculum and pharyngeal bone, orbit, muscles of the body, around the heart, abdominal cavity, mesentery, viscera and the swim bladder (Awachie, 1965). Clinostomum tilapiae n. sp. and Clinostomum phalacrocoracis Dubois, 1931 from Ghana (Ukoli, 1966). The adult trematode of Clinostomum are attached to the upper and lower jaws of cattle egrets, herons etc. Family Clinostomatidae has a widespread distribution. Members of this family have been recorded from the area where mean temperature is about $10^{\circ} \mathrm{C}$ (Grabda-Kazubska, 1974).
Infected cases of fish have been reported from Japan and Korea (Chung et al., 1995; Hiral et al., 1987; Isobe et al., 1994). C. complanatum and C. tilapiae have been recovered from African continent with Euclinostomum heterostomum being cosmopolitan. Metacercariae of Clinostomum complanatum have been recovered from Perca fluviatilis and Rutilus rutilus (Grabda-Kazubska, 1974), Plecoglossus altivelis (Lo et al., 1987), Misgurnus anguillicaudatus ( Lo et al., 1992), Carassius carassius, C. gibelio langsdrfi, C. cuvieri, Cobitis anguillicaudatus, Cyprinus carpio, Pseudogobio esocinus, Pseudorasbora parva, Rhodeus lanceolatus, $R$. ocellatus and Hypomesus transpacificus (Aohagi et al., 1993), Carassius sp (Aohagi and Shibaharam, 1994), Zacco temminki, Acheilognathus rhombea, Microphysogobio yaluensis, Carassius auratus (Chung, 1995), Lateolabrax japonicus, Leuciscus hakonensis (Aohagi et al., 1995), and Eutycea neotenes (Mitchell, 1995). Adult stage of the parasite has been recovered from Nycticorax nycticorax (Aohagi et al., 1992) and Ardea cinnerea (Lo et al., 1987; Aohagi et al., 1992). Metacercariae may affect growth and survival, or disfigure fish so that they lose their market value as a food or ornamental product (Paperna, 1991). Some metacercariae in fisheries and aquaculture products (fish and shellfish) are a source for infections in humans and domestic animals (Deardoff and Overstreet, 1991). 


\section{MATERIALS AND METHODS}

Study Area: Opi lake is a tropical freshwater lake located between $6^{0} 45^{\prime} 0^{\prime \prime}-45^{\prime} 28^{\prime \prime} \mathrm{N}$ and $7^{\circ} 29^{\prime} 28^{\prime \prime}-7^{0}$ $29^{\prime} 35^{\prime \prime} \mathrm{E}$ (GPS N06.75275*, E007.49104*) in the valley of river Uhere, Northeast of Nsukka, Enugu State, Nigeria. The lake is about 300 meters from Uhere river. The soil is porous and subject to sever erosion. The vegetation and climate of the lake area has been described (Hare and Carter, 1984). The lake has no permanent inlet, but during the flood period the lake overflows through a small channel at the southern end. The lake has a gentle sloppy shoreline with thick marginal vegetation (Inyang, 1995). The western side has a wide beach overgrown with saprophytes dominated by Crytosperma senegalenses (Schott); Jussiaea repens Var diffusa (Forsk) and Rynchospora sp. Its surface area and maximum depth (Zmax) fluctuate seasonally and range between 1.3 and 2.0 ha and 2.0 and $3.9 \mathrm{~m}$ respectively (Inyang, 1995). The mid lake deposit is mud mixed with coarse organic matter from the marginal vegetation on the other parts of the shoreline. The ichthyofauna of the lake includes Tilapia zillii, Hemichromis fasciatus, Parachana obscura, Malapterus electricus, Chrysicthys auratus, Epiplatys sexfasciatus, Hetrobranchus longifilis, Clarias angullaris, C. gariepinus, Barbus aboinensis, Nannaethiops unitaeniatus, Mormyrops engystoma and M. hasselguisti (Inyang, 1995).

Sampling: One hundred and seventy seven species of $S$. melanotheron (Olaosebikan and Raji, 1998) were caught using multiple fishing gear techniques (cast nets, hook and line and seine nets $(150 \mathrm{~mm}-$ $200 \mathrm{~mm}$ )) monthly (November 2007 - October 2008). Harvested fishes were transported in ice to Parasitology and Public Health Research laboratory, Department of Zoology, University of Nigeria, Nsukka for analysis.

Prevalence: Freshly caught fish were examined for parasites using procedure in Arthur and Albert (1994). Prevalence was calculated as the number of host infected divided by number of host examined expressed in percentage. Treatment, fixation and preservation of parasites were according to Ash and Orihel (1987).

Morphometrics: Eye piece and stage micrometers were used to measure the diameters of oral sucker (OS), ventral sucker (VS), and pharynx to the nearest 0.1 micrometers. Other measurements taken were body length $(\mathrm{BL})$, and the distance between oral and ventral suckers (DOVS) $(\mathrm{nm})$.

Data Analysis: Data generated were analyzed using the infection statistics of Bush et al. (1997), Rankabundance, species diversity and quantitative index of Shannon-Wienner index (Molles, 2002). Differences in various morphometric characters were established using analysis of variance with Duncan's post hoc. All statistical analysis were done using SPSS version 15 statistical package.

\section{RESULTS}

The prevalence of the clinostomatids was low; $C$. complanatum (9.4\%), E. heterostomum (10.4\%), and Clinostomum tilapiae (4.8\%) (Table 1). High mean intensities suggestive of heavy parasite burden were recorded thus; $C$. complanatum (4.2), C. tilapiae (2.0) and $E$. heterostomum (4.5). In all sampled fish species, fish size range $10-12 \mathrm{~cm}$ was most infected whereas fish size above $16 \mathrm{~cm}$ had the lowest level of infection. C. complanatum infection in fish size range of $10-12 \mathrm{~cm}$ gave the highest prevalence $(11.3 \%)$ and the lowest prevalence $(1.13 \%)$ occurred in fish size above $16 \mathrm{~cm}$. In the infection of $E$. heterostomum also, fish size range $10-12 \mathrm{~cm}$ had the highest prevalence $(2.25 \%)$ and the least was recorded by size range above $160.56 \%$. Similarly, in the infection of $C$. tilapiae fish size range of $10-12$ $\mathrm{cm}$ had the highest prevalence of $10.16 \%$ while the size range above $16 \mathrm{~cm}$ had lowest value of $1.13 \%$ (Table 2). Out of 177 S. melanotheron examined, 19 were infected by C. tilapiae, 38 infected by $C$. complanatum and $41 \mathrm{~S}$. melanotheron by $E$. heterostomum. 158 C. complanatum, $85 \mathrm{E}$. heterostomum and $87 \mathrm{C}$. tilapiae were recovered from the infected hosts. E. heterostomum (pi 0.48) was more abundant than the other two species (pi 0.26) (Figure 1). Duncan's one way analysis of variance for comparison of means of morphometric characters indicated that except for the oral sucker, $C$. complanatum and $E$. heterostomum differed in all other variables significantly from $C$. tilapiae $(P<0.05)$ (Table 3). The three major microhabitats viz: buccal cavity, skin and eye were inhabited by clinostomatid parasites. The buccal cavity had the highest infection when compared to the other microhabitats (eye and skin). The presence of these clinostomatids led to inflammation and haemorrhages developed during penetration and early migration. Damage of important organs (eye and skin) was recorded. Eye damage due to corneal infection resulted in total blindness and other degrees of eye infection; exophtalamus, necrotic cells and ulceration of the lining membranes. Roughening of the skin by bumps/ yellow grubs caused by encysting metacercariae was observed.

\section{DISCUSSION}

The prevalence of infection of the parasites in relation to size showed that the larger the fish the lower the infestation, possibly due to development of immunity against it. It was found that fish above $16 \mathrm{~cm}$ had lowest parasitic infection while those in the range of $10-12 \mathrm{~cm}$ had the highest level of infection. This agrees with the work of (Malek and Mobedi, 2001) usually one expects larger fish to have more parasites as they have been exposed to infection for longer time. The prevalence of parasites significantly decrease with increase in length and no significant difference were observed in abundance. Decrease in the prevalence of infection in the larger fish could be as a result of increase in the mortality of infected fish, increase in the built up humoral and non specific 
Table 1: Clinostomatids composition, overall prevalence and prevalence in relation to microhabitats in Sarotherodon melanotheron from Opi Lake

\begin{tabular}{|c|c|c|c|c|c|c|c|c|}
\hline $\begin{array}{l}\text { Parasite } \\
\text { species }\end{array}$ & $\begin{array}{l}\text { Host fish } \\
\text { and No of } \\
\text { infected } \\
\text { hosts }\end{array}$ & $\begin{array}{l}\text { Sex of } \\
\text { hosts }\end{array}$ & $\begin{array}{c}\text { No of } \\
\text { infected } \\
\text { host }\end{array}$ & $\begin{array}{l}\text { Microhabitats } \\
\text { in host fish }\end{array}$ & $\begin{array}{c}\text { Total } \\
\text { No of } \\
\text { Parasites }\end{array}$ & $\begin{array}{c}\text { "Prevalence } \\
(\%)\end{array}$ & $\begin{array}{c}\text { 9 Mean } \\
\text { intensity }\end{array}$ & ${ }^{\sharp}$ Abundance \\
\hline Clinostomum & $S$. & Male & 8 & B. cavity & 56 & 4.52 & 1.51 & 0.32 \\
\hline \multirow[t]{5}{*}{ complanatum } & melanotheron & $\prime \prime$ & 10 & Skin & 16 & 5.65 & 0.43 & 0.09 \\
\hline & $(n=177)$ & & 10 & Eye & 14 & 5.65 & 0.38 & 0.08 \\
\hline & infected & Female & 3 & B. cavity & 7 & 1.69 & 0.19 & 0.04 \\
\hline & hosts $=37$ & , & 3 & Skin & 4 & 1.69 & 0.11 & 0.02 \\
\hline & & $\prime$ & 3 & Eye & 3 & $\begin{array}{c}1.69 \\
(20.89)\end{array}$ & 0.08 & 0.02 \\
\hline Euclinostomum & $S$. & Male & 1 & B. cavity & 4 & 0.56 & 0.36 & 0.02 \\
\hline \multirow[t]{5}{*}{ heterostomum } & melanotheron & , & 1 & Skin & 2 & 0.56 & 0.18 & 0.01 \\
\hline & $(n=177)$ & & 1 & Eye & 2 & 0.56 & 0.18 & 0.01 \\
\hline & infected & Female & 2 & B. cavity & 13 & 1.23 & 1.18 & 0.07 \\
\hline & hosts $=11$ & , & 4 & Skin & 9 & 2.26 & 0.82 & 0.05 \\
\hline & & $\prime \prime$ & 2 & Eye & 2 & $\begin{array}{l}1.23 \\
(6.4)\end{array}$ & 0.18 & 0.01 \\
\hline Clinostomum & $S$. & Male & 10 & B. cavity & 70 & 5.65 & 1.89 & 0.40 \\
\hline \multirow[t]{5}{*}{ tilapiae } & melanotheron & "I & 14 & Skin & 56 & 7.91 & 1.51 & 0.32 \\
\hline & $(n=177)$ & & 6 & Eye & 15 & 3.39 & 0.41 & 0.08 \\
\hline & infected & Female & 2 & B. cavity & 41 & 1.23 & 1.11 & 0.23 \\
\hline & hosts $=37$ & $\prime \prime$ & 3 & Skin & 27 & 1.69 & 0.73 & 0.15 \\
\hline & & $\prime$ & 2 & Eye & 8 & $\begin{array}{c}1.23 \\
(21.1)\end{array}$ & 0.22 & 0.05 \\
\hline
\end{tabular}

Key: B. cavity = Buccal cavity жPrevalence: number of host infected divided by the number examined expressed as a percentage. "Mean intensity: Mean number of parasites per infected host. Abundance: Mean number of parasites per host examined. Number in parenthesis = total prevalence.

Table 2: Overall variations in the abundance and prevalence of Clinostomatids in different length groups

\begin{tabular}{|c|c|c|c|c|c|c|c|c|c|c|}
\hline $\begin{array}{l}\text { Length groups } \\
(\mathbf{c m})\end{array}$ & $\mathbf{N}$ & $\begin{array}{l}\text { Buccal } \\
\text { cavity }\end{array}$ & skin & Eye & $\begin{array}{c}\text { Prevalence } \\
\%\end{array}$ & $\begin{array}{c}\text { Mean } \\
\text { intensity }\end{array}$ & Abundance & $\begin{array}{c}\text { \% } \\
\text { Prevalence } \\
\text { of Buccal } \\
\text { cavity }\end{array}$ & $\begin{array}{c}\% \\
\text { Prevalence } \\
\text { of skin }\end{array}$ & $\begin{array}{c}\% \\
\text { prevalence } \\
\text { of eye }\end{array}$ \\
\hline \multicolumn{11}{|l|}{$\begin{array}{c}\text { C. } \\
\text { complanatum }\end{array}$} \\
\hline$<10$ & 4 & 9 & 3 & 2 & 2.30 & 3.50 & $0.08 \pm 0.98$ & 14.29 & 15.00 & 11.76 \\
\hline $10-12$ & 20 & 34 & 8 & 8 & 11.30 & 2.50 & $0.38 \pm 0.44$ & 53.97 & 40.00 & 47.05 \\
\hline $12-14$ & 8 & 12 & 6 & 4 & 4.51 & 2.75 & $0.12 \pm 0.69$ & 19.05 & 30.00 & 23.53 \\
\hline $14-16$ & 3 & 6 & 2 & 2 & 1.69 & 3.33 & $0.06 \pm 1.13$ & 9.52 & 10.00 & 11.76 \\
\hline Above 16 & 2 & 2 & 1 & 1 & 1.12 & 2.00 & $0.02 \pm 1.39$ & 3.17 & 5.00 & 5.88 \\
\hline \multicolumn{11}{|l|}{$\begin{array}{c}E . \\
\text { heterostomum }\end{array}$} \\
\hline$<10$ & 2 & 2 & 2 & 1 & 1.12 & 2.50 & $0.03 \pm 1.27$ & 11.76 & 18.20 & 25.00 \\
\hline $10-12$ & 4 & 9 & 7 & 2 & 2.25 & 4.50 & $0.08 \pm 0.90$ & 52.94 & 63.60 & 50.00 \\
\hline $12-14$ & 2 & 3 & 2 & 1 & 1.12 & 3.00 & $0.03 \pm 1.27$ & 17.65 & 18.20 & 25.00 \\
\hline Above 16 & 1 & 1 & - & - & 0.56 & 1.00 & $0.00 \pm 1.80$ & 5.88 & - & - \\
\hline \multicolumn{11}{|l|}{ C. tilapiae } \\
\hline$<10$ & 6 & 18 & 10 & 3 & 3.38 & 5.16 & $0.18 \pm 0.85$ & 16.22 & 12.05 & 13.04 \\
\hline $10-12$ & 18 & 51 & 39 & 12 & 10.16 & 5.67 & $0.58 \pm 0.49$ & 45.95 & 46.99 & 52.22 \\
\hline $12-14$ & 8 & 24 & 20 & 5 & 4.52 & 6.13 & $0.27 \pm 0.74$ & 21.62 & 24.10 & 21.74 \\
\hline $14-16$ & 3 & 11 & 9 & 2 & 1.69 & 7.33 & $0.12 \pm 1.21$ & 9.91 & 10.84 & 8.69 \\
\hline Above 16 & 2 & 7 & 5 & 1 & 1.13 & 6.50 & $0.07 \pm 1.48$ & 6.31 & 6.02 & 4.35 \\
\hline
\end{tabular}

0.00 is for values lower than 0.01

immunity against the parasites. Since temperature is not limiting in the tropics it is expected that antibody production and other immunological reactions are more active in tropical fish than temperate ones. As the small size fish survives the infection it grows to occupy new niches and acquire better microhabitat against parasitic infestation.
Clinostomatid metacercariae had predilection for the mesenteries of blood capillaries in the buccal cavity; this explains their high prevalence and abundance in the buccal cavity. The buccal cavity blood capillaries provide nutrients which the parasites feed on either through passive, active or facilitated diffusion. 


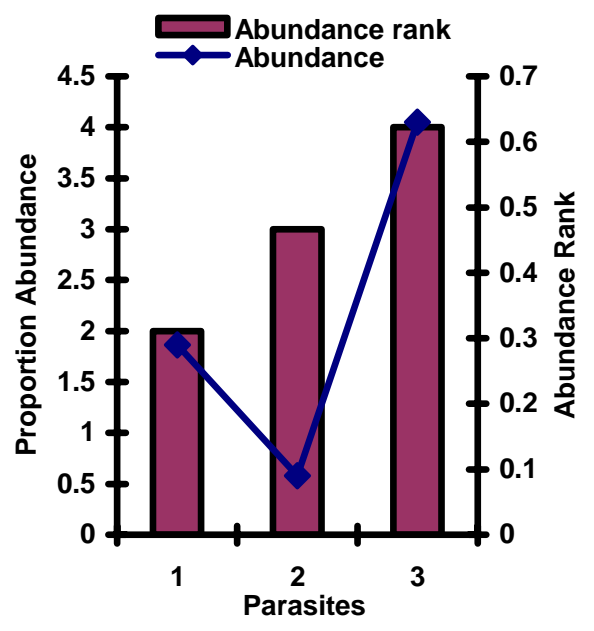

Figure 1: Communities of parasites in Sarotherodon melanotheron
Adaptation is a heritable trait that either spread because of natural selection or has been maintained by selection to the present or currently spreading relative to alternative traits because of natural selection. In all such cases, the trait in question has conferred and continues to confer or is just beginning to confer higher genetic or reproductive success on dominant species of the parasites with favorable alternative traits in the various fish species. In evolutionary biology, 'fitness' is a measure of an individual's reproductive or genetic success, so that 'fitness benefit' refers to the positive effect of a trait on the number of surviving offspring produced by an individual or the number of genes it contributes to the next generation whereas 'fitness cost' refers to the damaging effects of the trait on these measures of individual genetic success. Much the same type of thing has been documented for two strains of laboratory mice that are genetically identical in every respect, except for a single gene that encodes an enzyme called $\alpha$-calciumcalmodulin kinase. Because of this one genetic and enzymatic difference, members of the two strains differ in the construction of their hippocampus, a region of the vertebrate brain involved in spatial learning. These hippocampus differences between the two kinds of mice underlie differences in their performance on spatial memory tests (Silva et al., 1992). Suggestive pressures on selection for the fittest. Natural selection would favour $C$. tilapiae in $S$.

Relative larger morphometric body length of $C$. tilapiae would be more influx of nutrients than the other two species. Malek and Mobedi (2001), the higher prevalence and abundance of parasites in the area under the mouth to behind the operculum are probably due to the presence of blood, which Clinostomum complanatum feed on. It disagrees with the finding that the main habitat of Clinostomum complanatum in the Carassius sp was the muscles around the gills (Aohagi and Shibahara, 1994).

Two forms of occurrence of metacercariae in fish (encysted and excysted) possibly indicate some fish developed resistance to the metacercarial stage of Clinostomum. The later form; excysted metacercariae in the various localized sites could be more harmful to human health when they are consumed in semi cooked form. This is because attachment to the mucus membrane of pharynx of the definitive hosts (Egret, Herons etc) causes laryngopharyngitis. There were more excysted forms of $E$. heterostomum than the other two parasite species. Out of $32 \mathrm{E}$. heterostomum only 10 were not excysted, 37 C. tilapiae and 44 of $C$. complanatum were encysted respectively. These excysted forms caused serious damages to the infected fish. These effects include blindness, myositis, muscle bumps (yellow grubs) etc. This will affect the palatability and marketability of the infected fish as well as the acceptance of fish as the primary source of animal protein. melanotheron during the cause of time and possible domination in other fish hosts in this freshwater lake.

\section{REFERENCES}

AOHAGI, Y. and SHIBAHARA, T. (1994). Clinostomum complanatum infection in Carassius $s p$ colleted from some ponds and rivers in Tottori and Shimane Perfecture, Japan. Japanese Journal of Parasitology, 43: 129 135.

AOHAGI, Y., SHIBAHARA, T. and KAGOTA, K. (1993). Clinostomum complanatum (Trematoda) infection in freshwater fish from fish dealers in Tottori. Japanese Journal of Veterinary Medicine, 55:153 - 154.

AOHAGI, Y., SHIBAHARA, T. and KAGOTA, K. (1995). Metacercariae of Clinostomum complanatum found from new fish hosts. Lateolabrax japonicus and Leusiscus hakonensis. Japanese Journal of Parasitology, 44: 340 342.

AOHAGI, Y., SHIBAHARA, T., MACHIDA, N., YAMAGA, Y. and KAGOTA, K. (1992). Clinostomum complanatum (Trematoda: Clinostomatidae) in five fish hosts in Japan. Journal of Wildlife Disease, 28: 467 - 469.

AOHAGI, Y., SHIBAHARA, T. and KAGOTA, K. (1995). A newly recognized natural definitive host of Clinostomum complanatum (Rudolphi, 1814) 
in Japan. Japanese Journal of Parasitology, 42: $44-46$.

ARTHUR, J. R. and ALBERT, E. (1994). A survey of the parasites of Greenland halibut (Reinhardtius hippoglossoides) caught off Atlantic Canada, with notes on their zoogeography in this fish. Canadian Journal of Zoology, 72: 765 - 778.

ASH, L. R. and ORIHEL, T. C. (1987). Parasites: $A$ guide to laboratory procedures and identification. ASCP Press, Chicago.

AWACHIE, J. B. E. (1965). Preliminary notes on the parasites of fish in the area of Kainji reservoir. In: White (eds) The first Scientific Report of the Kainji Dam.

BUSH, A. O., LAFFERTY, D. K., LOTZ, M. J. and SHOSTAK, W. A. (1997). Parasitology meets ecology on its own terms: Margolis et al. Revisited. Journal of Parasitology, 83: 575 583.

CHUNG, D. I. KONG, H. H. and MOON, C. H. (1995). Demonstration of the second intermediate hosts of Clinostomum complanatum in Korea. Korean Journal of Parasitology, 33: 219 223.

DEARDORFF, T. L. and OVERSTREET, R. M. (1991). Seafood-transmitted zoonoses in the United States: the fishes, and the worms. In: WARD, D. R. and HACKENEY, C. (Eds) Microbiology of marine food products. Van Reinold, New York.

GRABDA-KAZUBSKA, B. (1974). Clinostomum complanatum (Rudolphi, 1819) and Euclinostomum heterostomum (Rudolphi, 1819) (Trematoda, Clinostomatidae), their occurrence and possibility of acclimatization in artificially heated lakes in Poland. Acta Parasitologica, 22: $285-293$.

HARE, L. and CARTER, J. C. H. (1984). Diet and seasonal fluctuations in a small natural West African lake. Freshwater Biology, 14: 597 610.

HIRAL, H., OOISO, H., KIFUNE, T., KIYATO, T. and SAKAGUCHI, Y. (1987). Clinostomum complanatum infection in posterior wall of pharynx of human. Japanese Journal of Parasitology, 36: $142-144$.

INYANG, N. M. (1995). On the fish fauna of Opi Lake, Southeastern Nigeria, with particular reference to the biology of Tilapia zillii (GERVAS, 1848) (Cichlidae). Journal of Aquatic Sciences, 10: $29-36$.
ISOBE, A. KINOSSHITA, S. HOJO, N. FUKUSHIMA, T. SHIWAKU, K. and YAMANE, Y. (1994). The $12^{\text {th }}$ human case of Clinostomum complanatum sp. infection in Japan. Japanese Journal of Parasitology, 43: 193 198.

LO, C., WANG, C. and KOU, G. (1992). The pathology of loach (Misgurnus anguillicandatus) infected with Clinostomum complanatum (Rudolphi, 1814). Acta Zoologica, 3:145 154.

LO, C., KOU, G., HUBER, F. and LIU, F. G. (1987). The study of Clinostomum complanatum (Rudolphi, 1814). The metacercariae of Clinostomum complanatum in the sweet fish (Plecoglossus altivelis). The Memoir of Parasitology in Fish Disease, 2: 56 - 63.

MALEK, M. and MOBEDI, I. (2001). Occurrence of Clinostomum complanatum (Rudolphi, 1819) (Digenea: Clinostomatidae) in Capoeta capoeta gracilis (Osteichthys: Cyprinidae) from Shroud River, Iran. Iranian Journal of Public Health, 4: 95 - 98.

MITCHELL, A. J. (1995). Importance of treatment duration for praziquantel used against larval digenetic trematodes in sunshine bass. Journal of Aquatic Animal Health, 7: 327 330.

MOLLES, M. C. (2002). Ecology: Concepts and Applications. McGraw Hill Publications, New York.

OLAOSEBIKAN, B. D. and RAJI, A. (1998). Field guide to Nigerian freshwater fishes. Federal College of Freshwater Fisheries Technology, New Bussa, Nigeria.

PAPERNA, I (1991). Diseases caused by parasites in the aquaculture of Warm fish. Annual Review of Fish Diseases, 1: 155 - 194.

SILVA, A., PAYLOR, J. R., WEHNER, J. M. and TONEGAWA, S. (1992). Impaired spatial learning in alpha - calcium-camodulin kinase II mutant mice. Science, 257: $206-211$.

UKOLI, F.M.A. (1966). On Clinostomum tilapiae n.sp. and Clinostomum phalacrocoracis Dubois, 1931, from Ghana and a discussion of the systematic of the genus Clinostomum Leidy, 1956. Journal of Helminthology, 40: 187 214.

UKOLI, F. M. A. (1969). On the life history, growth and development from the metacercarial stage to adulthood of Clinostomum tilapiae. Journal of Helminthology, 40: 215 - 226. 
Echi et al. 